\title{
Strategi Self-Regulated Learning untuk Menurunkan Tingkat Prokrastinasi Akademik Siswa
}

\author{
Muhammad Iqbalul Ulum \\ Universitas Pendidikan Indonesia, Jl. Dr. Setiabudhi No. 229 Bandung \\ e-mail:khansaarkana@gmail.com
}

\begin{abstract}
Academic procrastination is a behavior that should be avoided by students because it would give a bad influence, especially the academic achievement. One of the factors that lead to academic procrastination is lack of self-regulation in learning. Therefore, it is necessary for students to have self-regulated learning. This research aimed to test the self-regulated learning strategy to reduce the level of academic procrastination XI grade student of SMAN 1 Ngamprah of the academic year 2015/2016 West Bandung Regency. The method used is a quasi-experimental nonequivalent (pretest and posttest) control group design. Sampling was done by using purposive sampling technique. Instrument used is The Academic Procrastination State Inventory (APSI) developed by Henri C. Schouwenburg. The sample are 68 students whereas devided into experiment and control group. Data analyzed using the Mann-Whitney test. Result shows that self-regulated learning are effective for lowering the level of academic procrastination.
\end{abstract}

Keywords: strategies, self-regulated learning, academic procrastination

\begin{abstract}
Abstrak
Prokrastinasi akademik merupakan perilaku yang seharusnya dihindari oleh siswa karena akan memberikan pengaruh buruk, terutama terhadap prestasi akademiknya. Salah satu faktor yang menyebabkan prokrastinasi akademik adalah rendahnya regulasi diri dalam belajar. Oleh karena itu, perlu bagi siswa untuk memiliki regulasi diri dalam belajar. Penelitian ini bertujuan untuk menguji self-regulated learning untuk menurunkan tingkat prokrastinasi akademik siswa kelas XI SMAN 1 Ngamprah Tahun Pelajaran 2015/2016 Kabupaten Bandung Barat. Metode yang digunakan adalah kuasi eksperimen dengan nonequivalent (pretest dan posttest) control group design. Pengambilan sampel dilakukan dengan teknik purposive sampling. Teknik pengumpulan data mengunakan The Academic Procrastinasi State Inventory (APSI) yang dikembangkan oleh Henri C. Schouwenburg. Sampel penelitian berjumlah 68 siswa dengan pembagian 34 siswa untuk kelompok eksperimen dan 34 siswa untuk kelompok kontrol. Teknik analisis data menggunakan uji Mann-Whitney. Hasil uji statistik menunjukkan bahwa strategi self-regulated learning efektif untuk menurunkan tingkat prokrastinasi akademik.
\end{abstract}

Kata Kunci: strategi, self-regulated learning, prokrastinasi akademik

\section{Pendahuluan}

Belajar merupakan tugas utama seorang siswa, namun tidak semua siswa memiliki pengelolaan belajar yang baik, khususnya dalam kemampuan self-regulated learning. Pengaturan diri dalam belajar yang kurang baik menyebabkan siswa sering melakukan penundaan dalam mengerjakan tugas-tugas akademik. Perilaku menunda tugas-tugas akademik disebut dengan prokrastinasi Akademik.
Prokrastinasi akademik adalah perilaku penundaan pada tugas akademik yang dilakukan secara sadar dengan melakukan aktivitas lain yang menye-nangkan dan tidak penting, tidak bertujuan, tidak memperhatikan waktu sehingga menimbulkan akibat negatif atau kerugian pada pelakunya. Prokrastinasi adalah suatu kecenderungan untuk menunda dalam memulai maupun menyelesaikan kinerja secara keseluruhan untuk melakukan aktivitas lain yang tidak berguna, sehingga 
kinerja menjadi terhambat, tidak pernah menyelesaikan tugas tepat waktu, serta sering terlambat dalam menghadiri pertemuan-pertemuan (Solomon dan Rothblum, 1984). Sedangkan menurut Mc. Carthy (dalam LaForge, 2008), prokrastinasi adalah kecenderungan untuk menunda atau menghindari sepenuhnya tanggung jawab, keputusan, atau tugas yang perlu dilakukan, dan biasanya baru mulai dikerjakan pada saat-saat terakhir batas pengumpulan tugas.

Ferrari, Johnson dan Mc. Cown (1995) mengatakan bahwa sebagai suatu penundaan, prokrastinasi akademik dapat termanifestasikan dalam indikator tertentu yang dapat diukur dan diamati ciri-ciri tertentu berupa; penundaan untuk memulai maupun menyelesaikan kerja pada tugas yang dihadapi, keterlambatan dalam mengerjakan tugas, prokrastinator lebih sering menggunakan waktu luangnya untuk mengerjakan sesuatu yang tidak berhubungan dengan tugas utamanya, kesenjangan waktu antara rencana dan kinerja aktual, melakukan aktivitas lain yang lebih menyenangkan daripada melakukan tugas yang harus dilakukan.

Fenomena umum yang terjadi pada pelajar saat ini adalah sebagian pelajar tidak dapat memanfaatkan waktu dengan baik, sering mengulur waktu dengan melakukan kegiatan yang tidak bermanfaat sehingga waktu terbuang dengan sia-sia. Sebagian perilaku pelajar remaja banyak menghabiskan waktu hanya untuk urusan hiburan semata dibandingkan dengan urusan akademik. Hal ini terlihat dari kebiasaan suka begadang, jalan-jalan di mall atau plaza, menonton televisi hingga berjam-jam, kecanduan game online dan suka menunda waktu pekerjaan (Savitri, 2011).

Prokrastinasi merupakan perilaku yang diharapkan tidak terjadi dalam dunia akademik, sebab tindakan ini dapat menimbulkan konsekuensi berupa lumpuhnya kemajuan akademik (Burka dan Yuen, 2008), cenderung memperoleh nilai aka- demik rendah dan rata-rata kondisi kesehatan yang kurang baik (Sia, 2006), menurunkan kualitas hidup (Cox, dkk. dalam Kartadinata dan Tjundjing, 2008). Menurut Solomon dan Rothblum (1984), beberapa kerugian akibat kemunculan prokrastinasi akademik adalah tugas tidak terselesaikan, hasilnya tidak memuaskan, akan menimbulkan kecemasan bahkan kemudian depresi, tingkat kesalahan yang tinggi karena individu merasa tertekan, sulit berkonsentrasi, waktu yang terbuang, motivasi serta rasa percaya diri yang rendah.

Perilaku prokrastinasi akademik juga diduga terjadi pada siswa kelas XI SMAN 1 Ngamprah Kabupaten Bandung Barat. Berdasarkan hasil observasi terhadap beberapa siswa dan wawancara kepada Guru, ditemukan beberapa siswa melakukan penundaan terhadap tugas, sehingga saat mendekati deadline banyak tugas yang belum selesai dikerjakan. Banyak guru yang mengeluh karena siswa sering telat mengumpulkan tugas dan bahkan ada yang tidak mengerjakan sama sekali. Bahkan seorang guru melaporkan bahwa ada satu kelas yang pernah tidak mengerjakan tugas.

Alasan siswa dalam melakukan perilaku prokrastinasi cukup beragam, mulai dari kurangnya kemampuan dalam membagi waktu antara belajar dengan kegiatan ekstrakurikuler, sebagian terdapat siswa yang baru mengerjakan tugas menunggu moodnya bagus dan memilih melakukan aktivitas lain yang lebih menyenangkan. Beberapa siswa juga memilih menunda tugas karena menunggu tugas yang selesai dari siswa lain.

Individu yang memiliki self-regulation rendah cenderung melakukan tindakan prokrastinasi, karena kemampuan melakukan self-regulation atau pengaturan diri merupakan faktor yang penting yang mempengaruhi kemunculan perilaku prokrastinasi pada siswa (Steel, 2007). Selain itu Fischer (1999) menyatakan bahwa masalah utama pada prokrastinasi adalah 
ketidakmampuan memperkirakan jumlah waktu yang dibutuhkan dalam mengerjakan tugas. Oleh karena itu, dibutuhkan suatu usaha aktif dan mandiri untuk dapat membantu mengarahkan proses belajar pada tujuan belajar yang ingin dicapai, yang disebut dengan self-regulated learning.

Hal tersebut juga didukung dengan hasil penelitian yang dilakukan oleh Wolters (2003) yang mana hasil penelitiannya menunjukan bahwa ada hubungan antara prokrastinasi akademik dengan beberapa komponen penting dari self-regulated learning. Salah satu komponennya adalah kognitif yang dapat digunakan individu untuk mengontrol kognisi dalam proses belajar. Lebih lanjut Howell dan Watson (2007) menemukan bahwa prokrastinasi itu terjadi disebabkan rendah dan kurangnya kemampuan dalam belajar berdasar regulasi diri dan tidak memiliki waktu yang cukup untuk belajar.

Berdasarkan hal tersebut menun-jukan bahwa rendahnya kemampuan selfregulated learning menjadi penyebab terjadinya prokrastinasi akademik. Antara siswa yang memiliki self-regulated learning tinggi dengan yang memiliki selfregulated learning rendah, dapat dibedakan dari kemandirian siswa melalui usaha untuk mengatur diri mereka sendiri secara aktif dan mandiri yang meliputi pengaturan kognisi, motivasi, dan perilaku.

Zimmerman (1989) menekankan bahwa untuk dapat dikatakan sebagai seorang self-regulated learner, proses belajar seseorang harus melibatkan penggunaan strategi-strategi khusus untuk mencapai tujuan belajarnya. Selanjutnya Zimmerman (2002) menyatakan bahwa strategi-strategi self-regulated learning, yaitu fase forethought: (1) penetapan tujuan dan perencanaan strategi; fase performance: (2) penggunaan strategi yang ampuh, (3) pengaturan konteks lingkungan fisik dan sosial, (4) pengelolaan penggunaan waktu, (5) pengawasan selektif; fase selfreflection: (6) evaluasi diri, (7) atribusi penyebab, dan (8) adaptasi metode selanjutnya. Jadi, kuat lemahnya selfregulated learning seseorang dilihat dari keseluruhan strategi-strategi regulasi diri dalam belajar tersebut.

Adanya strategi self-regulated learning menjadi unsur penting dalam belajar sebab strategi tersebut akan berperan untuk menurunkan prokrastinasi akademik siswa dalam menyelesaikan tugas-tugas belajar, mengingat prok-rastinasi akademik merupakan perilaku yang seharusnya dihindari oleh siswa karena akan memberikan pengaruh buruk (Solomon dan Rothblum, 1984, Ferrari, dkk. 1995), terutama terhadap prestasi aka-demiknya. Dengan didasari hal-hal yang telah dikemukakan di atas, maka penelitian ini bertujuan untuk menguji efektivitas strategi self-regulated learning dalam me-nurunkan tingkat prokrastinasi akademik siswa.

\section{Prokrastinasi Akademik}

Prokrastinasi adalah kecenderungan untuk menunda atau menghindari sepenuhnya tanggung jawab, keputusan, atau tugas yang perlu dilakukan (Mc. Carthy, dkk. dalam LaForge, 2008). Prokrastinasi menurut Solomon dan Rothblum (dalam Brownlow dan Reasinger, 2000) adalah penundaan mulai pengerjaan maupun penyelesaian tugas yang disengaja. Dari definisi tersebut dapat dilihat bahwa perilaku prokrastinasi adalah perilaku yang disengaja, dalam arti bahwa faktor-faktor dalam menunda pengerjaan atau penyelesaian tugas berasal dari putusan dirinya sendiri.

Umumnya prokrastinasi diartikan sebagai kecenderungan irasional menunda untuk memulai atau menyelesaikan sebuah tugas. Perilaku ini melibatkan kesadaran pelaku prokrastinasi yang seharusnya melakukan tugas itu dan bahkan ingin untuk melakukan tugas itu, namun gagal memotivasi diri sendiri untuk melakukan tugas tersebut dalam jangka waktu yang diharapkan atau diharuskan (Ferrari dan Lay dalam Senécal dan Guay, 2000). 
Prokrastinasi akademik adalah perilaku menunda-nunda mengerjakan atau menyelesaikan tugas akademik (Ferarri, 1995), dan biasanya tugas baru mulai dikerjakan pada saat-saat terakhir batas tugas (Wolters, 2004). Prokrastinasi akademik merupakan penundaan yang dilakukan secara sengaja dan berulang-ulang baik memulai maupun menyelesaikan tugas yang berhubungan dengan bidang akademik (Husetiya, 2010).

Menurut Surijah dan Tjundjing (2007) aspek-aspek pada prokrastinasi akademik terdiri dari 4 hal, yaitu; (1) Perceived time, merupakan kecenderungan seorang prokrastinator salah satunya gagal menepati deadline.(2) Intention-action gap, merupakan celah antara keinginan dan perilaku. (3) Emotional distress, merupakan salah satu aspek yang tampak dari perasaan cemas saat melakukan prokrastinasi. (4) Perceived ability, merupakan keyakinan terhadap kemampuan diri pada seseorang. Keragu-raguan seseorang terhadap kemampuan diri akan menyebabkan seseorang melakukan prokrastinasi.

Menurut Ferrari, dkk. (1995), prokrastinasi akademik dapat termanifestasikan dalam indikator tertentu yang dapat diukur dan diamati dengan ciri-ciri berupa; (1) Penundaan untuk memulai maupun menyelesaikan kerja pada tugas yang dihadapi. Seseorang yang melakukan prokras-tinasi tahu bahwa tugas yang dihadapinya harus segera diselesaikan dan berguna bagi dirinya, akan tetapi dia menunda-nunda untuk mulai mengerjakannya atau menunda-nunda untuk menyelesaikan sampai tuntas jika dia sudah mulai mengerjakan sebelumnya.

Keterlambatan dalam mengerjakan tugas. Individu yang melakukan prokrastinasi memerlukan waktu yang lebih lama daripada waktu yang dibutuhkan pada umumnya dalam mengerjakan suatu tugas. Seorang prokratinator meng-habiskan waktu yang dimilikinya untuk mempersiapkan diri secara berlebihan, maupun melakukan hal-hal yang tidak dibutuhkan dalam penyelesaian suatu tugas, tanpa memperhitungkan keter-batasan waktu yang dimilikinya. (3) Kesenjangan waktu antara rencana dan kinerja aktual. Seorang prokrastinator mempunyai kesulitan untuk melakukan sesuatu sesuai dengan batas waktu yang telah ditentukan sebelumnya. Seorang prok-rastinator sering mengalami keter-lambatan dalam memenuhi deadline yang telah ditentukan, baik oleh orang lain maupun rencana yang telah dia tentukan sendiri. (4) Melakukan aktivitas lain yang lebih menyenangkan daripada melakukan tugas yang harus dikerjakan. Seorang prokrastinator dengan sengaja tidak segera melakukan tugasnya, akan tetapi menggunakan waktu yang dia miliki untuk melakukan aktivitas lain yang dipandang lebih menyenangkan dan mendatangkan hiburan, seperti membaca (koran, majalah, atau buku cerita lainnya), menonton, mengobrol, berjalan-jalan, mendengarkan musik, dan sebagainya, sehingga menyita waktu yang dia miliki untuk me-ngerjakan tugas yang harus diselesaikannya.

Menurut Green (dalam Ghufron, 2003), jenis tugas yang menjadi objek prokrastinasi akademik adalah tugas yang berhubungan dengan kinerja akademik. Adapun menurut Solomon dan Rothblum (1984), prokrastinasi terjadi secara merata dalam enam area fungsi akademis yaitu tugas mengarang, belajar untuk menghadapi ujian, membaca, tugas ad-ministrasi, menghadiri pertemuan dan kinerja akademik secara keseluruhan.

Bernard (dalam Catrunada dan Puspitawati, 2008), mengungkapkan ada sepuluh faktor yang dapat menyebabkan prokrastinasi, yaitu (1) Kecemasan (Anxiety), (2) Pencelaan terhadap diri sendiri (Self-depreciation), (3) Rendahnya toleransi terhadap ketidak-nyamanan (Low discomfort tolerance), (4) Pencari kesenangan (Pleasure-seeking), (5) Tidak teraturnya waktu (Time disorganization) (6) Tidak teraturnya lingkungan (Environmental disorganization), (7) Pendekatan 
yang lemah terhadap tugas (Poor task approach), (8) Kurangnya pernyataan yang tegas (Lack of assertion), (9) Permusuhan terhadap orang lain (Hostility with others), (10) Stres dan kelelahan (Stress and fatigue)

Sementara itu, Kartadinata dan Tjundjing (2008) mengungkapkan faktorfaktor lain yang menyebabkan munculnya prokrastinasi akademik antara lain manajemen waktu, penetapan prioritas, dan karakteristik tugas.

Masalah manajemen waktu. Manajemen waktu melibatkan proses menentukan kebutuhan (determining needs), menetapkan tujuan untuk mencapai kebutuhan (goal setting), memprioritaskan dan merencanakan (plan-ning) tugas yang diperlukan untuk men-capai tujuan.

Penetapan prioritas. Hal ini penting supaya individu bisa menangani semua masalah atau tugas secara runtut sesuai dengan kepen-tingannya.

Karakteristik tugas.Individu cenderung akan menunda mengerjakan tugas apabila dinilai sulit oleh individu tersebut. Hal ini juga dipengaruhi faktor motivasi baik intrinsik maupun ekstrinsik siswa.

Karakter individu. Mencakup perasaan kurang percaya diri, moody, dan keyakinan tak rasional. Individu cenderung melakukan pe-nundaan jika merasa kurang percaya diri dalam melaksanakan tugas karena takut terjadi kesalahan. Burka dan Yuen (2008) menegaskan aspek keyakinan tak rasional yang dimiliki individu, bahwa individu memiliki pandangan tugas harus diselesaikan dengan sem-purna, sehingga merasa lebih aman jika tidak mengerjakannya.

Menurut Ferrari, dkk. (1995) ada beberapa teori perkembangan yang menjelaskan terjadinya prokrastinasi akademik, antara lain psikodinamik, behavioristik, dan cognitive behavioral.

Psikodinamik. Penganut psikodinamik beranggapan bahwa pengalaman masa kanak-kanak mempengaruhi perkembangan proses kognitif seseorang ketika dewasa, terutama trauma. Seseorang yang pernah mengalami trauma akan suatu tugas tertentu, misalnya gagal me-nyelesaikan tugas sekolahnya, akan cenderung melakukan prokrastinasi ketika seseorang tersebut dihadapkan lagi pada suatu tugas yang sama.

Behavioristik. Penganut psikologi behavioristik ber-anggapan bahwa perilaku prokrastinasi akademik muncul akibat proses pem-belajaran. Seseorang melakukan prok-rastinasi akademik karena dia pernah mendapatkan reinforcement atas perilaku tersebut.

Cognitive behavioral. Prokrastinasi akademik terjadi karena adanya keyakinan irrasional yang dimiliki oleh seseorang. Keyakinan irrasional tersebut dapat disebabkan oleh suatu kesalahan dalam mem-persepsikan tugas.

Prokrastinasi merupakan perilaku yang diharapkan tidak terjadi dalam dunia akademik, sebab tindakan ini dapat menimbulkan konsekuensi berupa lumpuhnya kemajuan akademik (Burka dan Yuen, 2008). Selain itu prokrastinator cenderung memperoleh nilai akademik rendah dan rata-rata kondisi kesehatan yang kurang baik (Sia, 2006). Secara umum, prokrastinasi dapat menurunkan kualitas hidup prokrastinator (Cox, dkk. dalam Kartadinata dan Tjundjing, 2008).

Menurut Solomon dan Rothblum (1984), beberapa kerugian akibat kemunculan prokrastinasi akademik adalah tugas tidak terselesaikan, akan terselesaikan tetapi hasilnya tidak memuaskan disebabkan karena individu terburu-buru dalam menyelesaikan tugas tersebut untuk mengejar batas waktu pengumpulan, akan menimbulkan kecemasan sepanjang waktu sampai terselesaikan bahkan kemudian depresi, tingkat kesalahan yang tinggi karena individu merasa tertekan dengan batas waktu yang semakin sempit disertai dengan peningkatan rasa cemas sehingga individu sulit berkonsentrasi secara maksimal, waktu yang terbuang lebih ba- 
nyak dibandingkan dengan orang lain yang mengerjakan tugas yang sama dan akan dapat merusak kinerja akademik seperti kebiasaan buruk dalam belajar, motivasi belajar yang sangat rendah serta rasa percaya diri yang rendah.

Hal tersebut juga diperkuat oleh Ferrari, dkk. (1995), menurutnya prokrastinasi akademik banyak berakibat negatif. Dengan melakukan penundaan, banyak waktu terbuang sia-sia, tugas-tugas menjadi terbengkalai, bisa mengakibatkan individu kehilangan kesempatan dan peluang yang datang, serta berakibat pada performa tugas yang dihasilkan kurang maksimal.

\section{Self-Regulated Learning}

Menurut Zimmerman (1989, 2000) self-regulated learning adalah suatu strategi belajar dimana siswa secara metakognitif mempunyai motivasi atau dorongan untuk belajar dan berpartisipasi aktif dalam proses belajar mandiri. Lebih lanjut Zimmerman dan Martinez-Pons (1990) mendefinisikan self-regulated learning sebagai kemampuan siswa untuk berpartisipasi aktif dalam proses belajarnya, baik secara metakognitif, motivasional maupun behavioral. Sehingga individu yang belajar, dapat secara aktif menyusun dan menentukan tujuan belajar, merencanakan dan memonitor, mengatur dan mengontrol kognisi, motivasi, serta lingkungannya untuk mencapai tujuan yang telah ditetapkan (Filho, 2001, Pintrich, 2004, Wolters, 2003).

Winne (1997) mensyaratkan lima karakteristik yang harus ada pada individu yang menerapkan strategi self-regulated learning, yaitu: (1) harus bertujuan memperluas pengetahuan dan menjaga siswa dalam mencapai tujuan yang diinginkan, (2) siswa menyadari sepenuhnya kondisi emosi mereka sehingga mereka dapat menemukan solusi dan strategi dalam mengelola emosi mereka, (3) secara berkala siswa memonitor kemajuan pembelajaran sesuai tujuan yang diinginkan, (4) setelah siswa memonitor strategi yang digunakan, selanjutnya menyesuaikan dan memperbaiki strategi yang digunakan berdasarkan kemajuan yang dicapai, (5) dan yang terakhir, siswa melakukan evaluasi terhadap hambatan dan rintangan yang mungkin muncul kemudian melakukan adaptasi sesuai yang diperlukan.

Zimmerman (2000) memberikan gambaran dan ciri-ciri siswa yang menerapkan strategi self-regulated learning, diantaranya adalah adanya partisipasi aktif dalam belajar dari segi metakognitif, motivasi, dan perilaku. Hal yang sama juga diungkap oleh Corno (2001) dalam salah satu penelitiannya, yang mana ia membedakan karakteristik para siswa yang belajar dengan self-regulate dengan yang tidak, diantaranya: (1) Mereka familiar dan mengetahui bagaimana menggunakan suatu seri strategi kognitif (repetisi, elaborasi, dan organisasi) yang membantu mereka menyelesaikan, mengubah, mengatur, memperluas, dan memperoleh kembali informasi (recover information). (2) Mereka mengetahui bagaimana merencanakan, mengontrol dan mengatur proses mental mereka terhadap pencapaian tujuan-tujuan personal (metacognition). (3) Mereka menunjukan sejumlah keyakinan motivasional (motivational beliefs), seperti perasaan academic self-efficacy, penetapan tujuan-tujuan belajar, pengembangan emosi positif terhadap tugas-tugas, seperti kegembiraan, kepuasan, dan semangat yang tinggi. (4) Mereka merencanakan dan mengontrol waktu dan upaya yang digunakan untuk tugas-tugas, dan mereka mengetahui bagaimana membuat dan membangun lingkungan belajar yang baik, seperti menemukan tempat belajar yang cocok, dan pencarian bantuan (helpseeking) dari guru/teman sekelas ketika menemui kesulitan. (5) Untuk perluasan konteks yang diberikan, mereka menunjukan upaya-upaya yang lebih besar untuk ambil bagian dalam kontrol.

Zimmerman (1989) menekankan bahwa untuk dapat dikatakan seseorang itu 
self-regulated learner, proses belajar seseorang harus melibatkan penggunaan strategi-strategi khusus untuk mencapai tujuan belajarnya. Selanjutnya Zimmerman (2002) menyatakan bahwa strategi-strategi self-regulated learning, yaitu fase forethought: (1) penetapan tujuan dan perencanaan strategi; fase performance: (2) penggunaan strategi yang ampuh, (3) pengaturan konteks lingkungan fisik dan sosial, (4) pengelolaan penggunaan waktu, (5) pengawasan selektif; fase selfreflection: (6) evaluasi diri, (7) atribusi penyebab, dan (8) adaptasi metode selanjutnya. Jadi, kuat lemahnya selfregulated learning seseorang dilihat dari keseluruhan strategi-strategi regulasi diri dalam belajar ini.

Self-regulated learning mengintegrasikan banyak hal tentang belajar efektif. Pengetahuan, motivasi dan disiplin diri atau volition (kemauan diri) merupakan faktor-faktor yang dapat mempengaruhi self-regulated learning (Woolfolk, 2008). Pengetahuan yang dimaksud adalah pengetahuan tentang dirinya sendiri, materi, tugas, strategi untuk belajar dan kontekskonteks pembelajaran yang akan digunakan.

Seorang self-regulated learner mengambil tanggung jawab terhadap kegiatan belajar mereka. Mereka mengambil alih otonomi untuk mengatur dirinya, mendefinisikan tujuan dan masalah-masalah yang mungkin akan dihadapinya dalam mencapai tujuan-tujuannya, mengembangkan standar tingkat kesempurnaan dalam pencapaian tujuan, dan mengevaluasi cara yang paling baik untuk mencapai tujuannya. Mereka memiliki jalan alternatif atau strategi untuk mencapai tujuan dan beberapa strategi untuk mengoreksi kesalahan dan mengarahkan kembali dirinya ketika perencanaan yang dibuatnya tidak berjalan. Mereka mengetahui kelebihan-kelebihan dan kekurangan-kekurangannya dan mengetahui bagaimana cara memanfaatkannya secara produktif dan konstruktif. Mereka juga mampu membentuk dan mengelola perubahan (McCombs dan Marzano, 1990).

Siswa yang belajar dengan regulasi diri bukan hanya tahu tentang apa yang dibutuhkan oleh setiap tugas, tetapi juga dapat menerapkan strategi yang dibutuhkan. Ketika mereka menjadi lebih memiliki pengetahuan, kesadaran atau inteligensi dalam suatu bidang, mereka akan menerapkan banyak strategi secara otomatis. Karenanya, mereka telah menguasai repertoar strategi dan cara pembelajaran yang fleksibel (Woolfolk, 2008).

\section{Strategi Self-Regulated Learning untuk Menurunkan Tingkat Prokrastinasi Akademik}

Salah satu faktor yang mem-pengaruhi prokrastinasi akademik adalah selfregulated learning. Hal ini didukung dengan hasil penelitian yang dilakukan oleh Wolters (2003) yang mana hasil penelitiannya menunjukan bahwa ada hubungan antara prokrastinasi akademik dengan beberapa komponen penting dari self-regulated learning. Salah satu komponennya adalah kognitif yang dapat digunakan individu untuk mengontrol kognisi dalam proses belajar.

LaForge (2008) menyatakan bahwa prokrastinasi dapat terjadi apabila kurangnya kemampuan atau adanya ketidakmampuan individu dalam belajar berdasar regulasi diri. Hal tersebut juga didukung oleh Howell dan Watson (2007) dan Wolters (2003) yang menemukan bahwa prokrastinasi itu terjadi disebabkan rendah dan kurangnya kemampuan dalam belajar berdasar regulasi diri dan tidak memiliki waktu yang cukup untuk belajar.

Kemampuan melakukan selfregulation atau pengaturan diri juga merupakan faktor yang penting yang mempengaruhi kemunculan perilaku prokrastinasi pada siswa (Steel, 2007). Individu yang memiliki self-regulation rendah cenderung melakukan tindakan prokrastinasi. 
Berdasarkan hal tersebut menunjukan bahwa rendahnya kemampuan selfregulated learning menjadi penyebab terjadinya prokrastinasi akademik. Zimmerman (1989) menekankan bahwa untuk dapat dikatakan seseorang itu sebagai self-regulated learner, proses belajar seseorang harus melibatkan penggunaan strategi-strategi khusus untuk mencapai tujuan belajarnya.

Self-regulated learning adalah pikiran, perasaan, dan perilaku yang di-prakarsai oleh diri sendiri untuk mencapai tujuan (Zimmerman, 2002). Self-regulated learning terdiri atas tiga siklus tahapan, yaitu fase forethought; (1) penetapan tujuan dan perencanaan strategi, fase performance; (2) penggunaan strategi yang ampuh, (3) pengaturan konteks lingkungan fisik dan sosial, (4) pengelolaan penggunaan waktu, (5) pengawasan selektif, dan fase self-reflection; (6) evaluasi diri, (7) atribusi penyebab, dan (8) adaptasi metode selanjutnya. Jadi, kuat lemahnya selfregulated learning seseorang dilihat dari keseluruhan strategi-strategi regulasi diri dalam belajar ini.

\section{Metode Penelitian}

\section{Metode dan Desain Penelitian}

Pendekatan yang digunakan dalam penelitian ini adalah pendekatan kuantitatif. Metode yang digunakan peneliti adalah kuasi eksperimen yaitu penelitian yang membandingkan dua kelompok sasaran penelitian. Desain eksperimen digunakan untuk menguji kemungkinan pengaruh dari variabel strategi self-regulated learning terhadap variabel perilaku prokrastinasi akademik siswa (Creswell, 2012). Dalam penelitian ini rancangan yang digunakan adalah nonequivalent (pretest dan posttest) control group design, yaitu dengan melakukan pengukuran sebanyak dua kali sebelum dan sesudah pemberian perlakuan.
Tabel 1

Desain Penelitian

\begin{tabular}{llll} 
& Pretest & Treatment & Posttest \\
\hline Eksperimen & $\mathrm{O}$ & $\mathrm{X}$ & $\mathrm{O}$ \\
Kontrol & $\mathrm{O}$ & & $\mathrm{O}$ \\
\hline (Campbell dan Stanley, & 1963, Mertens, 2010)
\end{tabular}

\section{Populasi dan Sampel Penelitian}

Penelitian dilaksanakan di SMA Negeri 1 Ngamprah Kabupaten Bandung Barat. Populasi dalam penelitian ini adalah siswa kelas XI IPA Tahun Pelajaran 20152016 yang berjumlah 82 siswa. Pengambilan sampel dalam penelitian ini dilakukan dengan cara purposive sampling. Sampel penelitian berjumlah 68 siswa yang dibagi menjadi dua kelompok, kelompok pertama merupakan kelompok eksperimen yakni sebanyak 34 siswa diberikan perlakuan berupa strategi self-regulated learning, sedangkan kelompok kedua merupakan kelompok kontrol yang tidak mengikuti strategi self-regulated learning yakni sebanyak 34 siswa.

Strategi self-regulated learning dalam penelitian ini adalah suatu bentuk pelatihan yang diberikan kepada siswa kelas XI SMAN 1 Ngamprah untuk me-ngatur diri dalam belajar yang ditandai dengan karakteristik: (1) dapat menetapkan tujuan belajar dan membuat perencanaan strategis untuk mencapai tujuan belajar serta memiliki keyakinan dan motivasi diri tentang belajar; (2) dapat mengendalikan diri untuk menggunakan strategi belajar dan mengamati peristiwa belajar; dan (3) dapat merefleksi dan mengevaluasi kemajuan diri dalam belajar sesuai tujuan belajar yang telah ditetapkan. Pemberian strategi self-regulated learning ini dilakukan selama 1 hari terdiri atas 6 sesi dengan durasi waktu 60 menit tiap sesi.

Strategi self-regulated learning yang diberikan dalam penelitian ini berupa pemberian materi, diskusi kelompok, latihan dan games. Adapun materi dalam pelatihan terdiri atas pemahaman prokrastinasi, strategi regulasi diri dalam belajar, goal setting, time management, self-management, dan motivasi. 
Teknik Pengumpulan dan Analisis Data

Untuk mengukur variabel bebas dalam penelitian ini, maka digunakan skala perilaku prokrastinasi akademik dengan model Likert yang menggunakan lima alternatif jawaban, yang merupakan hasil pengembangan yang diadaptasi berdasarkan indikator prokrastinasi akademik dari Schouwenburg (dalam Ferrari, dkk., 1995) yaitu: penundaan memulai dan menyelesaikan tugas akademik, kesenjangan waktu antara rencana dengan kinerja aktual, kecenderungan melakukan aktivitas lain yang lebih menyenangkan, takut gagal, dan kurang motivasi.

Analisis data yang digunakan dalam penelitian ini meliputi data yang diperoleh dari hasil pretest dan hasil posttest. Data yang diperoleh dianalisis untuk menjawab pertanyaan penelitian. Analisis data bertujuan untuk mengungkap efektivitas strategi self-regulated learning untuk menurunkan tingkat prokrastinasi akademik siswa. Adapun analisis data dalam penelitian ini menggunakan statistika nonparametrik yaitu uji U-Mann Whitney.

\section{Hasil Penelitian dan Pembahasan}

Hasil

Prokrastinasi akademik dalam penelitian ini diukur dengan menggunakan skala prokrastinasi akademik, semakin tinggi skor total yang diperoleh maka menunjukan semakin tinggi prokrastinasi akademik subjek. Demikian pula sebaliknya, semakin rendah skor total yang diperoleh subjek menunjukan semakin rendah prokrastinasi akademik subjek.

Secara umum tingkat prokrastinasi akademik siswa kelas XI SMAN 1 Ngamprah baik pada kelompok eksperimen maupun kelompok kontrol berada pada kategori sedang dengan prosentase sebesar $79 \%$ dan pada kategori tinggi sebesar $20 \%$.
Tabel 2

Prosentase Tingkat Prokrastinasi Akademik Siswa Kelompok Eksperimen dan Kelompok Kontrol Sebelum Dilakukan Treatment

\begin{tabular}{llllll}
\hline Kategori & Interval & \multicolumn{2}{c}{$\begin{array}{c}\text { Kelas } \\
\text { Eksperimen }\end{array}$} & \multicolumn{2}{c}{$\begin{array}{c}\text { Kelas } \\
\text { Kontrol }\end{array}$} \\
\hline & & $f$ & $\%$ & $f$ & $\%$ \\
\hline Tinggi & $\geq 132$ & 7 & 20.6 & 7 & 20.6 \\
Sedang & $95-131$ & 27 & 79.4 & 27 & 79.4 \\
Rendah & $\leq 94$ & 0 & .00 & 0 & .00 \\
\hline Jumlah & & 34 & 100 & 34 & 100 \\
\hline
\end{tabular}

Hasil ini berarti bahwa siswa masih melakukan penundaan pada tugas akademik dengan beralih melakukan aktivitas lain yang menyenangkan dan tidak penting, tidak bertujuan, dan tidak memperhatikan waktu sehingga pelaku mendapatkan akibat negatif atau merasa rugi atas perbuatannya itu.

Berdasarkan hasil uji statistik bahwa tingkat prokrastinasi akademik siswa SMAN 1 Ngamprah secara umum pada kelompok eksperimen yang diberikan strategi self-regulated learning mengalami penurunan yang signifikan apabila dibandingkan dengan kelompok kontrol yang tidak diberikan strategi self-regulated learning.

Tabel 3

Hasil Uji Mann-Whitney Skor Gain Pretest dan Posttest Tingkat Prokrastinasi Akademik Siswa Kelompok Eksperimen dan Kelompok Kontrol

\begin{tabular}{ll}
\hline & N-Gain \\
\hline Mann-Whitney U & 364.500 \\
Wilcoxon W & 959.500 \\
$Z$ & -2.620 \\
Asymp. Sig. (2-tailed) & .009 \\
\hline \multicolumn{2}{l}{ a. Grouping Variable: Eksperimen Kontrol }
\end{tabular}

Hasil uji Mann-Whitney memperlihatkan nilai signifikansi (sig.) sebesar 0.009 lebih kecil dari $\alpha=0.05$, yang berarti bahwa strategi self-regulated learning efektif untuk menurunkan tingkat prokrastinasi akademik siswa.

Berikut gambaran berdasarkan se-tiap aspek tingkat prokrastinasi akademik siswa pada kelompok eksperimen setelah diberikan treatment berupa strategi self- 
regulated learning sebagaimana tersaji pada grafik di bawah ini.

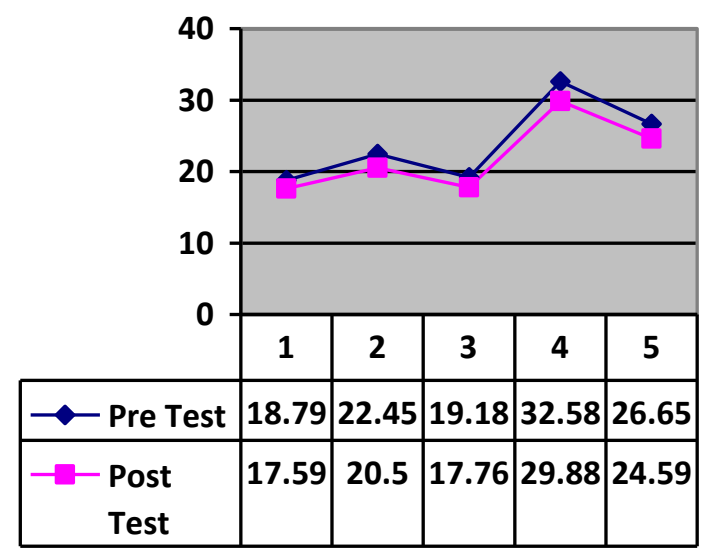

Gambar 1. Tingkat Prokrastinasi Akademik Siswa setiap Aspek pada Kelompok Eksperimen setelah Dilakukan Treatment

Berdasarkan pada grafik di atas, menunjukan perubahan data kelompok eksperimen saat pretest dan posttest. Pada aspek 1, penundaan memulai dan menyelesaikan tugas akademik, terjadi penurunan pada saat pretest dengan rata-rata 18,79 menjadi 17,59 pada saat posttest. Pada aspek 2, kesenjangan waktu antara rencana dengan kinerja aktual, terjadi penurunan saat pretest dengan rata-rata 22,45 menjadi 20,5 pada saat posttest. Pada aspek 3, kecenderungan melakukan aktivitas lain yang lebih menyenangkan, terjadi penurunan saat pretest dengan rata-rata 19,18 menjadi 17,76 pada saat posttest. Pada aspek 4, takut gagal, terjadi penurunan saat pretest dengan rata-rata 32,58 menjadi 29,88 pada saat posttest. Pada aspek 5, kurang motivasi, terjadi penurunan saat pretest dengan rata-rata 26,65 menjadi 24,59 saat posttest.

\section{Pembahasan}

Prokrastinasi akademik adalah perilaku penundaan pada tugas akademik yang dilakukan secara sadar dengan melakukan aktivitas lain yang me-nyenangkan dan tidak penting, tidak ber-tujuan, tidak memperhatikan waktu se-hingga menimbulkan akibat negatif atau kerugian pada pelakunya. Prokrastinasi akademik dalam penelitian ini diukur dengan menggunakan skala prokrastinasi akademik, semakin tinggi skor total yang diperoleh maka menunjukan semakin tinggi prokrastinasi akademik subjek. Demikian pula sebaliknya, semakin rendah skor total yang diperoleh subjek menunjukan semakin rendah prokrastinasi akademik subjek.

Secara umum tingkat prokrastinasi akademik siswa kelas XI SMAN 1 Ngamprah berada pada kategori sedang dengan prosentase sebesar $79 \%$ dan pada kategori tinggi sebesar 20\%. Hasil ini berarti bahwa siswa masih melakukan penundaan pada tugas akademik dengan beralih melakukan aktivitas lain yang menyenangkan dan tidak penting, tidak bertujuan, dan tidak memperhatikan waktu sehingga pelaku mendapatkan akibat negatif atau merasa rugi atas perbuatannya itu.

Berdasarkan hasil uji statistik bahwa tingkat prokrastinasi akademik sis-wa SMAN 1 Ngamprah pada kelompok eksperimen yang diberikan strategi selfregulated learning mengalami penurunan yang signifikan apabila dibandingkan dengan kelompok kontrol yang tidak diberikan strategi self-regulated learning. Hasil uji Mann-Whitney memperlihatkan nilai signifikansi (sig.) sebesar 0.009 lebih kecil dari $\alpha=0.05$, yang berarti bahwa strategi self-regulated learning efektif untuk menurunkan tingkat prokrastinasi akademik siswa. Hasil ini sesuai dengan ungkapan Winne (1997) yang menyatakan bahwa karakteristik dari siswa yang mempunyai regulasi diri dalam belajar diantaranya bertujuan memperluas pengetahuan dan menjaga motivasi, menyadari keadaan emosi dan mempunyai strategi untuk mengelola emosinya, secara periodik memonitor kemajuan ke arah tujuannya, menyesuaikan atau memperbaiki strategi berdasarkan kemajuan yang telah dibuat, mengevaluasi hambatan yang mungkin muncul dan melakukan adaptasi yang diperlukan. Berdasarkan penelitian ini terbukti bahwa siswa yang mampu me- 
ngadopsi dan menguasai strategi selfregulated learning maka strategi tersebut dapat mereka terapkan untuk mengurangi perilaku prokrastinasi akademik.

Penelitian lain yang dilakukan oleh Park dan Sperling (2011) menunjukan bahwa prokrastinasi akademik berhubungan dengan kemampuan regulasi yang buruk. Steel (2007) menyatakan bahwa kemampuan melakukan self-regulated learning merupakan faktor yang penting yang mempengaruhi kemunculan perilaku prokrastinasi akademik siswa.

Wolters (2003), menunjukan hasil penelitiannya bahwa ada hubungan antara prokrastinasi akademik dengan beberapa komponen penting dari self-regulated learning. Salah satu komponennya adalah kognitif yang dapat digunakan individu untuk mengontrol kognisi dalam proses belajar.

LaForge (2008) menyatakan bahwa prokrastinasi dapat terjadi apabila kurangnya kemampuan atau adanya ketidakmampuan individu dalam belajar berdasar regulasi diri. Hal tersebut juga didukung oleh Howell dan Watson (2007) serta Wolters (2003) yang menemukan bahwa prokrastinasi itu terjadi disebabkan rendah dan kurangnya kemampuan dalam belajar berdasar regulasi diri dan tidak memiliki waktu yang cukup untuk belajar.

Hasil penelitian lain oleh Savira dan Suharsono (2013) terhadap siswa akselerasi menunjukan bahwa siswa yang memiliki self-regulated learning yang tinggi maka prokrastinasi akademiknya rendah dengan prosentase $37,5 \%$. Sebaliknya, siswa dengan self-regulated learning rendah maka diikuti tingginya prokrastinasi akademik dengan prosentase 43,8\%. Hal ini diperkuat berdasarkan hasil penelitian Koushki, Liaght dan Kamali (2014) yang menyatakan bahwa individu yang memiliki keterampilan self-regulation rendah akan cenderung melakukan prokrastinasi dibandingkan dengan individu yang memiliki keterampilan self-regulation tinggi.
Beberapa strategi dalam self-regulated learning sebagaimana dike-mukakan oleh Zimmerman (2002) yaitu fase forethought: (1) penetapan tujuan dan perencanaan strategi; fase performance: (2) penggunaan strategi yang ampuh, (3) pengaturan konteks lingkungan fisik dan sosial, (4) pengelolaan penggunaan waktu, (5) pengawasan selektif; fase self-reflection: (6) evaluasi diri, (7) atribusi penyebab, dan (8) adaptasi metode se-lanjutnya, tampaknya berhasil diadopsi oleh siswa sehingga siswa memiliki mo-tivasi, tujuan, dan strategi untuk mengatur diri secara lebih baik, sehingga mengurangi tingkat prokrastinasi akademik mereka.

Faktor perencanaan merupakan suatu proses menetapkan tujuan yang hendak dicapai. Dalam proses ini siswa mengembangkan strategi, mengidentifikasi tantangan atau kesulitan yang akan dihadapi. Hal tersebut dapat dilakukan dengan cara melakukan analisis terhadap tugas, mencermati dan menentukan sumber-sumber yang dapat dipergunakan untuk membantu dalam mencapai tujuan, serta menentukan target atau hasil akhir yang diinginkan. Adapun siswa yang tidak menjalankan strategi ini akan mengerjakan tugasnya secara tidak teratur serta memulai untuk mengerjakannya kapan saja, yang mana pada awal mengerjakan tugas saja siswa sudah memunculkan perilaku prokrastinasi akademik. Hal tersebut sesuai dengan apa yang diungkapkan Wolters (2003) bahwa seseorang yang mempunyai suatu tujuan akan terhindar dari perilaku menunda yang akhirnya akan mempengaruhi munculnya motivasi intrinsik.

Pada fase performance yang merupakan bagian dari strategi selfregulated learning adanya faktor pengawasan yang mana melibatkan kemampuan untuk melakukan pengamatan dan mengukur kemajuan yang telah dicapai. Hal tersebut dimaksudkan supaya siswa yang bersangkutan dapat mengidentifikasi hal-hal apa saja yang masih membutuhkan perbaikan dan upaya perubahan demi 
mencapai tujuan yang telah ditetapkan sebelumnya. Semua hal ini dapat mengefektifkan pengerjaan tugasnya sehingga siswa tidak lagi melakukan hal-hal lain di luar konteks pengerjaan tugas yang dapat menghambat penyelesaian tugasnya. Oleh karena itu, siswa yang menjalankan strategi ini akan dapat mengerjakan tugasnya dengan waktu yang cukup sehingga ia akan terhindar dari prokrastinasi akademik, yaitu membuang-buang waktunya untuk melakukan hal lain di luar tugasnya.

Agar perubahan yang terjadi dapat terarah dan dapat dipertahankan maka aspek penguatan merupakan bagian penting, yang mana penguatan dapat dilakukan dengan cara merefleksikan dan mengenali keberhasilan. Siswa akan memantau apakah dirinya sudah melaksanakan rencananya atau belum (performa). Siswa juga dapat melihat sudah sampai mana hasil tugas yang telah dikerjakan. Terakhir, siswa juga akan memantau apakah kondisi dirinya dan lingkungan membantunya untuk mengefektifkan proses pengerjaan tugasnya. Jadi, jika ada niat untuk melakukan prokrastinasi akademik, maka siswa akan menghindarinya sebab ia tahu mengenai kemajuan yang sudah dicapainya.

Perencanaan yang baik yang kemudian diimbangi dengan kemampuan implementasi dan strategi evaluasi yang sesuai akan membuat siswa mampu mengurangi kesalahan yang dilakukan dalam menggunakan waktu sehingga perilaku prokrastinasi yang biasa dilakukan akan menurun. Berbagai aspek tersebut mempengaruhi siswa melakukan strategi self-regulated learning untuk mengurangi kebiasaan penundaan yang selama ini dilakukan.

Secara terperinci Schouwenburg (dalam Ferrari, dkk., 1995) menyebutkan dua faktor yang menyebabkan seseorang melakukan prokrastinasi. Faktor pertama yang terdiri dari: manajemen waktu, disiplin kerja, kontrol diri, harapan untuk sukses, motivasi belajar. Faktor kedua yang terdiri dari: inadequacy, takut gagal, kecemasan saat menghadapi ujian, kecemasan saat evaluasi, stress selama belajar dan depresi. Temuan-temuan penelitian sebelumnya menunjukan prokrastinasi dapat diprediksi melalui berbagai faktor, diantaranya adalah defisiensi regulasi-diri, motivasi yang rendah, pusat kendali-diri eksternal, perfeksionis, manajemen waktu yang lemah (Ackerman dan Gross, 2005).

Majemen waktu, penghindaran tugas, takut gagal merupakan faktor yang berhubungan dengan perilaku prokrastinasi. Pintrich dan DeGroot (1990) menyatakan bahwa individu yang memiliki regulasi diri dalam belajar adalah individu yang memiliki partisipasi aktif dan konstruktif serta memiliki potensi untuk menilai dan mengontrol kognisi, motivasi, perilaku dan lingkungan belajarnya. Karakteristik lain dari individu dengan regulasi diri dalam belajar yaitu individu yang memiliki unsur motivasi internal, metode pembelajaran, manajemen waktu, manajemen tempat, manajemen lingkungan sosial yang keseluruhannya dapat berpengaruh terhadap menurunnya perilaku prokrastinasi (Zimmerman dan Martinez-Pons, 1990).

Siswa yang menjalankan strategi pengelolaan penggunaan waktu akan berusaha berkomitmen untuk menepati tujuan dan rencana yang telah dibuat. Siswa akan memperkirakan waktu yang dibutuhkannya untuk mengerjakan tugas. Ketika waktunya tiba untuk mengerjakan tugas, ia akan menepatinya. Adapun siswa yang tidak menjalankan strategi ini akan membutuhkan waktu yang lebih lama dalam mengerjakan tugas sebab perkiraannya akan waktu yang dibutuhkan untuk mengerjakan tugas ternyata salah. Ia juga akan mudah terdistraksi untuk melakukan hal lain sehingga ia tidak dapat menepati tujuan dan rencananya, yang mana mengerjakan tugas menjadi lebih lama dari waktu yang dibutuhkan pada 
umumnya dan melakukan hal lain merupakan ciri dari prokrastinasi akademik.

Beberapa penelitian mencoba mengukur hubungan prokrastinasi dan manajemen waktu. Lay (dalam Kartadinata dan Tjundjing, 2008) menemukan korelasi negatif antara trait prokrastinasi dan subskala Time Management Behavior Scale (TMBS). Lebih jelasnya bahwa pelaku prokrastinasi menggunakan lebih sedikit manajemen waktu dari pada bukan pelaku prokrastinasi. Lebih lanjut Kartadinata dan Tjundjing (2008) berdasarkan hasil penelitiannya menjelaskan bahwa semakin tinggi kemampuan manajemen waktu seseorang, maka semakin rendah prokrastinasinya. Hal ini berarti bahwa seseorang yang mempunyai kemampuan dalam manajemen waktu dipengaruhi oleh faktorfaktor perilaku seperti: menetapkan tujuan dan prioritas, mekanisme perencanaan dan penjadwalan, kesukaan terhadap pengorganisasian, dan persepsi kontrol atas waktu (Macan dalam Kartadinata dan Tjundjing, 2008).

Dalam pendekatan strategi cognitivebehavioral, Burka dan Yuen (2008) mengemukakan bahwa pendekatan manajemen waktu dapat membantu individu mengatasi perilaku prokrastinasi. Strategi ini berhubungan dengan penetapan tujuan dengan cara membuat tujuan dalam tugas secara jelas, membuat tindakan yang spesifik, konkret dan membaginya dalam langkah-langkah kecil.

Berdasarkan hasil penelitian dari tingkat prokrastinasi akademik pada aspek 4 yaitu takut gagal, data pretest kelompok eksperimen dengan rata-rata 32,58 menjadi rata-rata 29,88 setelah diberikan strategi self-regulated learning. Hal tersebut sejalan dengan apa yang disebutkan Ferrari, dkk. (1995) bahwa prokrastinasi adalah sesuatu yang komplek yang berkaitan dengan variabel kepribadian. Ada beragam motif terjadinya prokrastinasi tetapi motif utamanya adalah takut gagal, tugas yang tidak menyenangkan, tugas yang sulit dan membosankan. Hal tersebut diperkuat oleh Solomon dan Rothblum (1984) bahwa motif dasar dari perilaku prokrastinasi akademik adalah takut akan kegagalan dan menghindari mengerjakan tugas.

Ellis dan Knaus (dalam Ferrari, dkk., 1995) memberikan penjelasan tentang prokrastinasi akademik dari sudut pandang cognitive-behavioral. Prokrastinasi akademik terjadi karena adanya keyakinan irrasional yang dimiliki oleh seseorang. Keyakinan irrasional tersebut dapat disebabkan oleh suatu kesalahan dalam mempersepsi tugas sekolah, seseorang memandang tugas sekolah sebagai sesuatu yang berat dan tidak menyenangkan (aversiveness of the task and fear of failure). Oleh karena itu seseorang akan merasa tidak mampu untuk menyelesaikan tugasnya secara memadai, dan akhirnya menunda untuk menyelesaikan tugas tersebut.

Menurut Burka dan Yuen (2008) seseorang melakukan prokrastinasi akademik karena takut akan gagal (fear of failure). Fear of Failure merupakan ketakutan yang berlebihan untuk gagal, siswa yang menunda mengerjakan tugas sekolahnya karena takut jika gagal menyelesaikannya, atau tidak sesuai dengan harapan guru dan dirinya sehingga akan mendatangkan penilaian negatif akan kemampuan dirinya. Akibatnya siswa akan menunda untuk mengerjakan tugas yang dihadapinya.

Steel (dalam Ilfiandra, 2006) menyatakan dalam teorinya bahwa perilaku prokrastinasi berdasarkan pada teori anxiety, fear of failure dan perfectionism, artinya individu melakukan prokrastinasi karena merasa takut dan stres. Penyebabnya adalah adanya keyakinan irrasional seperti takut gagal dan selalu ingin sempurna. Koushki, dkk. (2014) dalam penelitiannya menemukan bahwa karakteristik individu yang pesimis yang mengakibatkan perasaan rendah diri, kurangnya keberanian dan takut gagal merupakan penyebab internal siswa melakukan prokrastinasi. 
Selanjutnya, berdasarkan hasil pada aspek 5 yaitu kurang motivasi, yang mana rata-rata pretest sebesar 26,65 menjadi 24,59. Hal ini disebabkan karena motivasi merupakan faktor internal yang dimiliki oleh siswa yang kapasitasnya dapat digunakan untuk performa dan prestasi belajar. Besarnya motivasi yang dimiliki seseorang juga akan mempengaruhi prokrastinasi secara negatif, dimana semakin tinggi motivasi intrinsik yang dimiliki individu ketika menghadapi tugas, akan semakin rendah kecenderungannya melakukan prokrastinasi akademik (Briordy dalam Ferrari, dkk., 1995, Specter dan Ferrari, 2000).

Steel (2007) dalam penelitiannya menemukan bahwa faktor motivasi berprestasi berhubungan dengan perilaku prokrastinasi akademik. Hal tersebut disebabkan karena individu yang melakukan prokrastinasi merasa tidak menyukai tugas tertentu, menganggap bahwa tugas tidak menyenangkan. Akibatnya individu yang tidak memiliki motivasi berprestasi akan merasa kesulitan dalam menentukan tujuan bagi dirinya sendiri.

Beberapa hal tersebut di atas menguatkan kesimpulan yang didapatkan dari uji hipotesis utama mengenai efektivitas strategi self-regulated learning untuk menurunkan tingkat prokrastinasi akademik siswa. Hasil penelitian menunjukan bahwa strategi self-regulated learning dapat menurunkan tingkat prokrastinasi akademik siswa, namun terdapat beberapa keterbatasan yang perlu menjadi perhatian, diantaranya: penelitian ini hanya sebatas menguji efektivitas strategi self-regulated learning untuk menurunkan tingkat prokrastinasi akademik siswa secara statistik, sehingga perlu dilakukan pengujian secara empirik mengenai tingkat prokrastinasi akademik siswa. Perlu dilakukan tindak lanjut dengan cara melakukan wawancara ulang kepada guru-guru terkait dengan perilaku siswa yang berhubungan dengan perilaku prokrastinasi akademik siswa. Selain itu, tindak lanjut juga perlu dilakukan terhadap siswa untuk melihat secara empirik dampak pada tingkat prokrastinasi akademik siswa setelah diberikan strategi self-regulated learning. Keterbatasan lain adalah pada penelitian ini pemberian intervensi hanya berlangsung selama satu hari, sehingga perlu kiranya untuk menambah waktu intervensi agar hasilnya lebih efektif.

\section{Simpulan dan Saran}

\section{Simpulan}

Berdasarkan hasil penelitian bahwa strategi self-regulated learning dalam penelitian ini terbukti efektif untuk menurunkan tingkat prokrastinasi akademik siswa. Artinya tingkat prokrastinasi akademik siswa pada kelompok eksperimen yang diberikan strategi self-regulated learning mengalami penurunan yang signifikan apabila dibandingkan dengan kelompok kontrol yang tidak diberikan strategi self-regulated learning. Penurunan tersebut juga berlaku dalam setiap aspek prokrastinasi akademik siswa yaitu: penundaan untuk memulai maupun menyelesaikan tugas, kesenjangan waktu antara rencana dan kerja aktual, melakukan aktivitas lain yang lebih menyenangkan, takut gagal, dan kurang motivasi.

\section{Saran}

Hasil penelitian ini menyatakan bahwa strategi self-regulated learning efektif untuk menurunkan tingkat prok-rastinasi akademik siswa. Oleh karena itu diharapkan para pendidik dapat menerapkan strategi self-regulated learning sebagai alternatif pemecahan masalah prokrastinasi akademik.

Hasil penelitian ini menunjukan bahwa prokrastinasi akademik dapat diturunkan dengan melakukan strategi self-regulated learning sehingga para pelajar disarankan untuk dapat menguasai proses-proses regulasi diri.

Bagi para akademisi dan peneliti selanjutnya yang akan mengungkap masalah prokrastinasi akademik hendaknya 
menggunakan strategi lain baik itu yang menyangkut self-regulated learning secara lebih khusus maupun strategi yang berbeda sehingga dapat menambah alternatif pemecahan masalah yang berkaitan dengan prokrastinasi akademik.

\section{Daftar Pustaka}

Ackerman, D. S. dan Gross, B. L. 2005. My Instructor Made Me Do It: Task Characteristics of Procrastination, Journal of Marketing Education, 27(1), 5-13. doi:10.1177/0273475304273842.

Brownlow, S. dan Reasinger, R. D. 2000. Putting off until Tomorrow what is Better Done Today: Academic Procrastination as a Function of Motivation toward College Work, Journal of Social Behavior and Personality, 15(5), 15-34.

Burka, B. J. dan Yuen, L. M. (2008). Procrastination: Why Do it, New York: Perseus Book.

Campbell, D. T. Dan Stanley, J. C. (1963). Experimental and Quasi-Experimental Design for Research, USA.

Catrunada, Linda dan Puspitawati, Ira. (2008). Perbedaan Kecenderungan Prokrastinasi Tugas Skripsi Berdasarkan Tipe Kepribadian Introvert dan Ekstrovert, Jakarta: Program Sarjana Fakultas Psikologi Universitas Gunadarma.

Corno, L. (2001). Volitional Aspects of Self-Regulated Learning, In Zimmerman, B. J. dan Schunk, D. H. (Eds.) Self-Regulated Learning and Academic Achievement: The Theoretical Perspectives (2nd edn., pp. 191-226), Mahwah, NJ: Lawrence Erlbaum.

Creswell, J. W. (2012). Educational Research : Planning, Conducting, and Evaluating Quantitative and Qualitative Research (edisi keempat), Boston: Pearson Education, Inc.
Ferrari J. R., Johnson, J. L. dan Mc. Cown, W. G. (1995). Procrastination and Task Avoidance Theory, Research and Treatment, New York: Plenum Press.

Filho, M. K. C. (2001). A Review on Theories of Self-Regulation of Learning, Bull. Grad. Shool Educ. Hiroshima Univ, Part III.

Fischer, C. (1999). Read this Paper Later: Procrastination with Time-Inconsistent Preference, New York: Resources for The Future.

Ghufron, M. N. (2003). Hubungan Kontrol Diri dan Persepsi Remaja terhadap Penerapan Disiplin Orangtua dengan Prokrastinasi Akademik. Tesis. Program Pascasarjana Universitas Gadjah Mada.

Howell, A. J. dan Watson, D. C. 2007. Procrastination: Associations with Achievement Goal Orientation and Learning Strategies, Personality and Individual Differences, 43, 167-178.

Husetiya, Y. (2010). Hubungan Asertivitas dengan Prokrastinasi Akademik pada Siswa Fakultas Psikologi Universitas Diponegoro Semarang. Diakses melalui eprints.undip.ac.id/24780/1/jurnal1_mi ma.pdf.

Ilfiandra. (2006). Model Konseling Berdasarkan Pendekatan KognitifPerilaku untuk Mempercepat Penyelesaian Tugas Akademik Mahasiswa, Disertasi. Universitas Pendidikan Indonesia.

Kartadinata, Iven dan Tjundjing, Sia. 2008. I Love Tomorrow: Prokrastinasi Akademik dan Manajemen Waktu, Anima, Indonesian Psychological Journal, 23, 109-119.

Koushki, S., Liaght, R. dan Kamali, A. R. 2014. Relationship between Attributional Styles, Self-Regulation and Educational Procrastination in Student, International Journal of Psychology and Research, 3 (3), 184191. 
LaForge, M. C. 2008. Applying Explanatory Style to Academic Procrastination, Journal of Clemson University, 16 (2), 418-529.

McCombs, B. L. dan Marzano, R. J. 1990. Putting the Self in Self-Regulated Learning: The Self as Agent in Integrating Skill and Will,

Educational Psychologist, 25, 51-70.

Mertens, M. D. (2010). Research and Evaluation in Education and Psychology (Edisi ketiga), California: Sage Publication, Inc.

Park, Seung Won dan Sperling, Rayne A. 2011. Academic Procrastinators and their Self-Regulation, Psychology, 2012 (31), 12-23.

Pintrich, P. R. dan DeGroot, E. V. 1990. Motivational and Self-Regulated Learning Components of Classroom Academic Performance, Journal of Educational Psychology, 82 (1), 33-40.

Pintrich, P. R. 2004. A Conceptual Framework for Assesing Motivation and Self-Regulated Learning in College Students, Educational Psychology Review, 16, 386-407.

Savira, Fitria \& Suharsono, Yudi. 2013. Self-Regulated Learning (SRL) dengan Prokrastinasi Akademik pada Siswa Akselerasi, Jurnal Ilmiah Psikologi Terapan, 01 (01).

Savitri, I. (2011). Arti Belajar Penting Ditanamkan pada Anak Usia Sekolah, LPTUI. Diakses dari http://artikel.php.htm.

Senécal, C. dan Guay, F. 2000. Procrastination in Job-Seeking: An Analysis of Motivational Processes and Feelings of Hopelessness, Journal of Social Behavior and Personality, 15 (5), 267-282.

Sia, T. D. 2006. Apakah Prokrastinasi Menurunkan Prestasi? Sebuah MetaAnalisis, Anima, Indonesian Psychological Journal, 22 (1), 17-27.

Solomon L. J. dan Rothblum E. D. 1984. Academic Procrastination: Frequency and Cognitive-Behavioral Correlates,
Journal of Counseling Psychology, 33 (4), 503- 509.

Specter, M. H. dan Ferarri, J. R. 2000. Time Orientation of Procrastinators: Focusing on the Past, Present, or Future?, Journal of Social Behavior and Personality, 15 (5), 197-202.

Steel, P. 2007. The Nature of Procrastination: A Meta-Analytic and Theoretical Review of Quint Essential Self-Regulatory Failure, Psychological Bulletin, 133 (1), 65-94.

Surijah, E. A. dan Tjundjing, Sia. 2007. Mahasiswa Versus Tugas: Prokrastinasi Akademik dan Conscientiousness, Anima, Indonesian Psychological Journal, 22 (4), 352374.

Winne, P. H. 1997. Experimenting to Bootstrap Self-Regulated Learning, Journal of Educational Psychology, 89, 397-410.

Wolters, C. A. 2003. Understanding Procrastination from a Self-Regulated Learning Perspectives, Journal of Educational Psychology, 95 (1), 179187.

Wolters, C. A. 2004. Advancing Achievement Goal Theory Using Goal Structures and Goal Orientations to Predict Student's Motivation, Cognition, and Achievement, Journal of Educational Psychology, 11 (2), 158-163.

Woolfolk, A. E. (2008). Educational Psychology, Active Learning Edition, Tenth Edition, Boston: Allyn \& Bacon.

Zimmerman, B. J. 1989. A Social Cognitive View of Self-Regulated Academic Learning, Journal of Educational Psychology. 81 (3), 329339.

Zimmerman, B. J. (2000). Attaining SelfRegulation a Social Cognitive Perspective. In Boekerts, M., Pintrich, P. R., Zaidner, M. (Eds.) Handbook of Self-Regulation, California: Academic Press. 
Zimmerman, B. J. dan Martinez-Pons.

1990. Students Differences in Self-

Regulated Learning: Relating Grade, S

ex, and Giftedness to Self-Efficacy and Strategy Use, Journal of Educational Psychology, 82 (1), 51-59.

Zimmerman, B. J. 2002. Becoming a SelfRegulated Learner: An Overview Theory into Practice, College of Education, 41 (2). 
Psympathic, Jurnal Ilmiah Psikologi Desember 2016, Vol. 3, No. 2, Hal: 153 - 170 